\title{
Jumlah Trombosit pada Mencit Diabetes setelah Pemberian Ekstrak Rumput Laut Merah (Rhodophyceae)
}

\section{(Thrombocyte Level in Diabetic Mice after Red Seaweed (Rhodophyceae) Extract's Treatment)}

\author{
Dahna Maudita Kartikasari ${ }^{1}$, Didin Erma Indahyani ${ }^{2}$, Depi Praharani ${ }^{3}$ \\ ${ }^{1}$ Fakultas Kedokteran Gigi, Universitas Jember \\ ${ }^{2}$ Bagian Biomedik, Fakultas Kedokteran Gigi, Universitas Jember \\ ${ }^{3}$ Bagian Periodonsia, Fakultas Kedokteran Gigi, Universitas Jember \\ Jln. Kalimantan No.37, Kampus Tegalboto, Jember 68121 \\ e-mail: maudita1996@gmail.com
}

\begin{abstract}
Oxidative stress in diabetes mellitus triggers activation and increases in platelet counts that play a role in the formation of platelet plugs in the blood clotting process. If excessive blood clots occur, there is a risk of cardiovascular disease. Red seaweed extract contains carotenoids, phenols and their derivatives, fikobilin pigments, polysaccharide sulfates, and vitamins. The biggest phenol compound is flavonoids which are compounds that can produce platelet antia-gregation effects. The purpose of this study was to examine the effect of giving red seaweed extract to platelet counts in diabetic mice. The study group consisted of the treatment group of red seaweed extract, normal control, positive control and negative controls. The dosage of seaweed extract as much as $10 \mathrm{mg} / 20 \mathrm{grBB}$ is given in condition. The calculation of platelet count is carried out directly with the Brecher Cronkite method using a calculated room Improved Neubauer. The One Way ANOVA test results showed a significance value $(p<0.05)$, that is, the group of diabetic mice given red seaweed extract had a lower platelet count of $280000 \mu l$ compared to diabetic mice given metformin as much as $379000 \mu \mathrm{l}$. The decrease is due to flavonoids, saponins, alkaloids, $\beta$ carotene, vitamins and minerals able to stabilize the production of megakaryocytes and platelets, prevent the destruction of pancreatic $\beta$ cells and prevent free radicals. It was concluded that red seaweed extract can reduce platelet counts of diabetic mice near normal values.
\end{abstract}

Keywords : Oxidative stress, Diabetes Mellitus, Thrombocyte, Seaweed Extract

\begin{abstract}
Abstrak
Stress oksidatif pada diabetes melitus memicu aktivasi dan peningkatan jumlah trombosit yang berperan pada pembentukan sumbat trombosit dalam proses pembekuan darah. Apabila pembekuan darah terjadi berlebihan akan beresiko penyakit kardiovaskuler. Ekstrak rumput laut merah mengandung karotenoid, fenol dan turunannya, pigmen fikobilin, sulfat polisakarida, dan vitamin. Senyawa fenol terbesar yaitu flavonoid merupakan senyawa yang dapat menghasilkan efek antiagregasi trombosit. Tujuan penelitian ini mengkaji pengaruh pemberian ekstrak rumput laut merah terhadap jumlah trombosit pada mencit diabetes. Kelompok penelitian terdiri dari kelompok perlakuan ekstrak rumput laut merah, kontrol normal, kontrol positif dan kontrol negatif. Dosis ekstrak rumput laut sebanyak $10 \mathrm{mg} / 20 \mathrm{grBB}$ diberikan secara sondasi. Penghitungan jumlah trombosit dilakukan secara langsung dengan metode Brecher Cronkite menggunakan kamar hitung Improved Neubauer. Hasil uji One Way ANOVA menunjukkan nilai signifikansi $(p<0,05)$, yaitu kelompok mencit diabetes yang diberi ekstrak rumput laut merah mempunyai jumlah trombosit yang lebih rendah sebanyak $280000 \mu$ libandingkan mencit diabetes yang diberi metformin sebanyak $379000 \mu$ l. Penurunan tersebut oleh karena flavonoid, saponin, alkaloid, $\beta$ karoten, vitamin dan mineral mampu menstabilkan produksi megakariosit dan trombosit, mencegah destruksi sel $\beta$ pankreas serta mencegah radikal bebas. Disimpulkan bahwa ekstrak rumput laut merah dapat menurunkan jumlah trombosit mencit yang diabetes mendekati nilai normal.
\end{abstract}

Kata kunci: Stress oksidatif, Diabetes melitus, Trombosit, Ekstrak rumput laut 


\section{Pendahuluan}

Diabetes melitus merupakan kondisi hiperglikemia (peningkatan glukosa darah) yang disebabkan oleh gangguan sekresi insulin yang tidak memadai dalam mengangkut glukosa ke sel sehingga glukosa terkumpul di dalam darah $[6,13]$. Pada hiperglikemia terjadi peningkatan produksi radikal bebas akibat autooksidasi glukosa sehingga meningkatkan stress oksidatif yang dapat menyebabkan kerusakan berbagai organ, salah satunya pembuluh darah [3].

Kerusakan pembuluh darah tidak hanya berakibat pada diskontinuitas dari pembuluh darah, akan tetapi berakibat pada trombosit. Trombosit ini berperan dalam pembekuan darah, membentuk sumbatan dalam proses hemostasis. Trombosit harus dipertahankan dalam jumlah yang nomal terutama pada kondisi hiperglikemia, dimana terjadi peningkatan produksi trombosit oleh megakariosit dan peningkatan pelepasan trombosit ke aliran darah untuk membentuk sumbatan trombosit pada endotel yang rusak. Jumlah trombosit akan semakin meningkat apabila kadar gula darah yang terus meningkat $[2,13,22]$.Trombosit yang melekat pada dinding pembuluh darah yang rusak akan menghasilkan adenosine diphospate (ADP) yang menyebabkan trombosit membentuk agregat dan akhirnya membentuk sumbatan trombosit untuk memulai pembekuan darah (koagulasi). Jika proses koagulasi dalam darah terjadi berlebihan (trombosis), dapat menyebabkan trombosis tersebut menjadi trombus dan emboli yang berperan terhadap peningkatan kejadian penyakit kardiovaskular pada DM $[10,13,22]$.

Penggunaan metformin golongan biguanid sebagai antidiabetik dalam jangka panjang beresiko pada kesehatan, resistensi dan tidak dapat langsung berpengaruh sebagai antitrombosit $[1,3]$. Obat alternatif dari sumber daya hayati laut yang potensinya belum banyak dieksplor dan memiliki nilai ekonomis tinggi, salah satunya yaitu rumput laut [21]. Rumput laut merah (Rhodophyceae) mengandung berbagai senyawa di antaranya karotenoid, fenol dan turunannya, pigmen fikobilin, sulfat polisakarida, mineral dan vitamin $[9,18]$. Kandungan tersebut berpotensi sebagai antioksidan, antitrombosit, antiinflamasi, antikanker, antibakteri, antimikroba dan antivirus [11]. Flavonoid merupakan senyawa fenol terbesar. Berdasarkan penelitian Shahriyari dan Yazdanparast (2009) pada ekstrak yang mengandung senyawa flavonoid, terbukti memiliki aktivitas antitrombosit dengan cara menghambat metabolisme asam arakidonat oleh cyclooxygenase $[16,17]$. Vitamin C sebagai antitrombosit mempengaruhi pembentukan trombosit dengan menstabilkan produksi sel megakarioblas dan megakariosit serta mencegah krusakan jaringan akibat radikal bebas [12]. Oleh karena itu, tujuan penelitian ini adalah untuk mengkaji pengaruh ekstrak rumput laut merah pada penurunan jumlah trombosit pada mencit diabetes.

\section{Metode Penelitian}

Terdapat 16 mencit yang dibagi menjadi 4 kelompok yaitu kelompok kontrol normal (KN) yaitu mencit tanpa diberi perlakuan apapun, kelompok kontrol negatif (K-) yaitu mencit diabetes yang tanpa perlakuan, kelompok kontrol positif $(\mathrm{K}+)$ yaitu mencit diabetes yang diberi metformin, kelompok RLM yaitu mencit diabetes yang diberi ekstrak rumput laut merah,. Rumput laut yang digunakan yaitu Kapphaphycus alvarezii didapatkan dari Desa Agel, Kecamatan Jangkar, Situbondo. Ekstrak rumput laut merah diperoleh dari rumput laut segar yang telah terpotong dan dihaluskan menggunakan blender lalu dikeringkan menggunakan freeze dryer pada suhu $-70^{\circ} \mathrm{C}$ selama \pm 3 hari sampai diperoleh serbuk kering. Serbuk tersebut dilarutkan dengan etanol $96 \%$ dan dilakukan ekstraksi menggunakan alat ultrasonik dengan suhu $<50^{\circ} \mathrm{C}$ selama 3 jam. Dilakukan penyaringan menggunakan kertas saring Whatman serta pergantian etanol setiap 1 jam sekali sebanyak 3 kali. Pertama, dengan perbandingan 1:5,5. Kedua dan ketiga, dengan perbandingan 1:4. Untuk memperoleh ekstrak cair digunakan rotary evaporator pada suhu $40^{\circ} \mathrm{C}$ dengan kecepatan $150 \mathrm{rpm}$. Kemudian dilakukan pengentalan menggunakan water bath agar diperoleh hasil ekstrak kental.

Diabetes pada mencit dilakukan dengan induksi aloksan, aloksan monohidrat diinjeksikan secara intraperitoneal pada hari ke 7-10 selama 3 hari dengan dosis $4,2 \mathrm{mg} / 20 \mathrm{grBB}$ mencit. Melakukan cek kadar glukosa darah pada hari ke 10 setelah induksi aloksan. Pengecekan tersebut dilakukan setelah mencit dipuasakan selama 812 jam (hanya disediakan air). Kadar glukosa darah mencit diamati pada hari ke 10 menggunakan glukometer. Tetesan darah pertama dari vena ekor dibuang, tetesan darah berikutnya diletakkan di strip test yang telah terpasang pada glukometer dan hasilnya akan 
tertera. Kadar glukosa darah diatas 175 mg/dl yang digunakan pada penelitian.

Selanjutnya mulai melakukan perlakuan pada kelompok $\mathrm{K}+$ dan ekstrak rumput laut merah pada hari ke 10 hingga hari ke 30 (21 hari) secara sondasi. Pada kelompok ekstrak rumput laut merah mencit diberi ekstrak dengan dosis 10 $\mathrm{mg} / 20 \mathrm{grBB}$, kontrol normal tidak diberi perlakuan apapun, kontrol positif diberi metformin dengan dosis $1,3 \mathrm{mg} / 20 \mathrm{grBB}$ dan kontrol negatif tidak diberi perlakuan setelah induksi aloksan 4,2 $\mathrm{mg} / 20 \mathrm{grBB}$. Pada hari ke

30 perlakuan dihentikan (terminasi) untuk selanjutnya dilakukan pengambilan darah melalui jantung.

Penghitungan jumlah trombosit cara langsung dilakukan dengan metode Brecher Cronkite menggunakan kamar hitung Improved Neubauer yaitu darah diencerkan dengan reagen ammonium oxalat $1 \%$ dengan perbandingan 1:100 sebanyak $10 \mu \mathrm{l}: 990 \mu \mathrm{l}$. Selanjutnya kamar hitung diisi dengan larutan (darah dan ammonium oxalat $1 \%$ ) yang telah homogen menggunakan mikropipet dimana 3-4 tetes pertama dibuang terlebih dahulu lalu selanjutnya digunakan untuk mengisi kamar hitung. Kamar hitung yang telah terisi diletakkan pada cawan petri yang berisi tissue basah dan ditunggu selama 10 menit agar trombosit mengendap. Trombosit dihitung dalam seluruh bidang besar ditengah kamar hitung (1 $\mathrm{mm}^{2}$ ) dengan mikroskop cahaya perbesaran 200x. Jumlah trombosit yang telah dihitung dikali 1000 untuk menghasilkan jumlah trombosit per $\mu \mathrm{l}$ darah, dengan nilai rujukan normal trombosit 150.000-400.000/ul darah.

\section{Hasil}

Jumlah trombosit pada mencit (Mus musculus) diabetes setelah pemberian ekstrak rumput laut merah (Rhodophyceae) dengan ratarata pada kelompok kontrol normal, kontrol negatif, kontrol positif dan RLM adalah sebagai berikut pada Gambar 1.

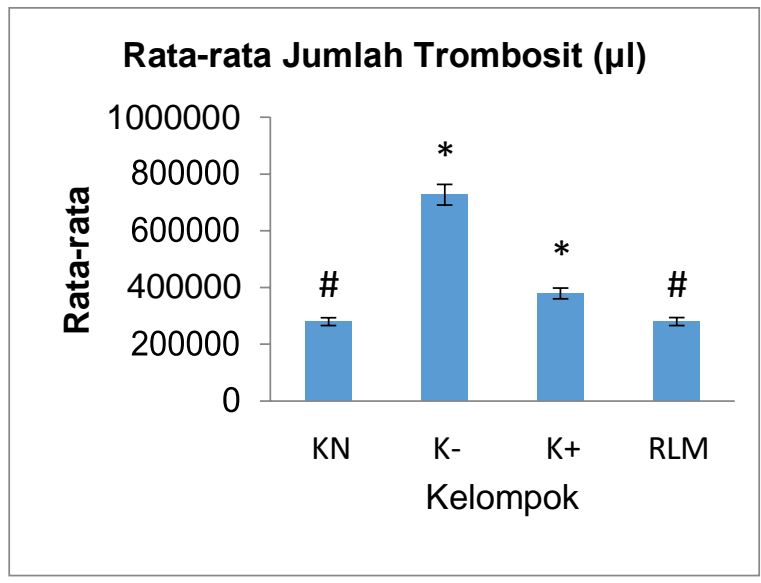

Gambar 1. Rata-rata jumlah trombosit pada mencit diabetes setelah perlakuan $(n=4)$.

Keterangan :

$\mathrm{KN}$ : Kontrol normal

K- : Kontrol negatif

$\mathrm{K}+$ : Kontrol positif

RLM : Perlakuan ekstrak rumput laut merah

$\mathrm{n}$ : Jumlah pengulangan

* : :Terdapat perbedaan yang signifikan antar semua kelompok perlakuan $(p<0,05)$

\# $\quad$ : Terdapat perbedaan yang signifikan antar semua kelompok perlakuan $(p<0,05)$ kecuali antar kelompok KN dengan RLM

Hasil penghitungan jumlah trombosit menggunakan kamar hitung Improved Neubauer dan mikroskop menunjukkan bahwa rata-rata jumlah trombosit diurutkan dari nilai tertinggi adalah K- yaitu sebanyak $727000 \mu \mathrm{l}, \mathrm{K}+$ yaitu sebanyak $379000 \mu \mathrm{l}$, RLM yaitu sebanyak $280000 \mu \mathrm{l}$ dan KN yaitu sebanyak $279000 \mu \mathrm{l}$.

Analisis data dilakukan uji normalitas menggunakan uji Shapiro-wilk dan uji homogenitas menggunakan uji Levene. Diperoleh hasil uji yang menunjukkan data berdistribusi normal dan homogen $(p>0,05)$. Selanjutnya dilakukan uji One Way Anova yang menunjukkan data berbeda signifikan $(p<0,05)$. Uji LSD menunjukkan nilai signifikansi $p<0,05$ dan ada kelompok dengan nilai signifikansi p>0,05 namun secara statistik menunjukkan adanya penurunan jumlah trombosit.

\section{Pembahasan}

Hasil penelitian ini sesuai dengan hipotesis bahwa pemberian ekstrak rumput laut merah dapat menurunkan jumlah trombosit pada mencit diabetes. Ekstrak rumput laut mampu menurunkan jumlah trombosit kemungkinan 
karena mempunyai kandungan senyawa flavonoid, saponin, alkaloid, karotenoid, vitamin dan mineral. Flavonoid merupakan senyawa yang dapat menghasilkan efek antitrombosit dengan cara menghambat metabolisme asam arakidonat oleh cyclooxygenase [10,17]. Flavonoid menghambat proses penggumpalan trombosit. Proses penggumpalan trombosit ini bermula dari adanya enzim fosfolipase $\mathrm{A} 2 \mathrm{di}$ dalam tubuh. Enzim fosfolipase A2 ini mengubah fosfolipid menjadi asam arakidonat. Asam arakidonat kemudian diubah oleh cyclooxygenase menjadi cyclic endoperoxides. Cyclic endoperoxides tersebut diubah menjadi prostacyclin (berada di saluran endothelium) dan thromboxane A2 (berada di dalam trombosit). Prostacyclin berperan dalam menghambat agregasi trombosit, sedangkan thromboxane A2 berperan dalam membantu terjadinya agregasi trombosit. Proses kerja thromboxane A2 inilah yang dihambat sehingga proses penggumpalan trombosit dapat dicegah dan jumlah trombosit dapat menurun [17]. Saponin, alkaloid dan $\beta$ karoten memiliki aktivitas antioksidan yang dapat menunjang efek antitrombosit. Antioksidan merupakan senyawa yang berguna mengatasi kerusakan oksidatif akibat radikal bebas dalam tubuh sehingga berperan mencegah berbagai macam penyakit, salah satunya mencegah peningkatan jumlah trombosit sebagai komplikasi dari keadaan hiperglikemia. Saponin, alkaloid dan $\beta$ karoten mampu meredam superoksida melalui pembentukan intermediet hidroperoksida sehingga mencegah kerusakan biomolekular oleh radikal bebas. Vitamin $\mathrm{C}$ sebagai antitrombosit mempengaruhi pembentukan trombosit dengan menstabilkan produksi sel megakarioblas dan megakariosit sehingga jumlah trombosit bertahan dalam jumlah yang normal. Vitamin dan mineral dapat mencegah kerusakan jaringan akibat radikal bebas [12]. Sedangkan senyawa polifenol mempunyai kemampuan untuk menyumbangkan atom hidrogen kepada senyawa radikal bebas sehingga terjadi penghentian reaksi berantai yang selanjutnya terjadi penuruan agregasi serta jumlah trombosit [19,23]. Penelitian Elsha Ukieyanna (2012) kandungan flavonoid mampu berperan menangkap radikal bebas [5].

Hasil uji statistik didapatkan tidak adanya perbedaan jumlah trombosit antara mencit normal dan mencit diabetes yang diberi ekstrak rumput laut merah. Berdasarkan hasil tersebut dapat disimpulkan bahwa ekstrak rumput laut yang lebih optimal dibandingkan metformin dalam menurunkan jumlah trombosit. Ekstrak rumput laut merah dalam menurunkan jumlah trombosit kemungkinan karena ekstrak rumput laut merah ini memiliki kandungan senyawa flavonoid yang terbesar. Senyawa fenol utamanya flavonoid dapat terabsorpsi dengan baik oleh tubuh sehingga paling efektif hasilnya $[8,10]$. Ekstrak rumput laut merah juga memiliki potensi besar sebagai antioksidan yang berasal dari kandungan polifenol, karotenoid, alkaloid, saponin, tannin. Menurut Shahriyari dan Yazdanparast (2009), ekstrak rumput laut merah flavonoid terbukti memiliki aktivitas antitrombosit yang menunjukkan terjadi penurunan jumlah trombosit [16]. Kadar air pada ekstrak rumput laut merah juga menunjukkan nilai yang kecil yaitu $13,90 \%$ sehingga diduga pengeluaran senyawa saat ekstraksi menjadi lebih banyak [4].

Pada kelompok mencit diabetes dan diberi pengobatan metfomin dengan dosis 1,3 mg/20grBB mencit [14]. Hasil penelitian menunjukkan kelompok mencit diabetes yang diberi metformin lebih tinggi dari yang diberi ekstrak rumput laut merah. Metformin merupakan obat antidiabetik oral yang dapat menurunkan kadar glukosa darah dengan cara kerja menghambat produksi glukosa hati (glukoneogenesis) [15]. Sehingga diduga obat tidak langsung berpengaruh pada penurunan jumlah trombosit sebagai antitrombosit. Selain itu, dikarenakan metformin sebagai obat lini pertama pada proses awal terapi yang digunakan sehingga apabila tidak optimal perlu diberikan obat kombinasi. Menurut penelitian dari [7]. Terdapat peningkatan pemberian kombinasi obat metformin dan glibenklamid dengan mekanisme berbeda karena pengobatan tidak dapat mencapai target.

Jumlah trombosit tertinggi didapatkan pada mencit diabetes yang tidak diberi perlakuan. Hal tersebut dikarenakan mencit mengalami diabetes tetapi hanya diberi makan dan minum standart, sehingga proses penyembuhan kondisi diabetiknya hanya dibantu oleh sistem imun tubuhnya sendiri. Pada kondisi diabetes terjadi peningkatan produksiitrombosit dan trombosit akaniteraktivasi dalam kerusakan endotel yang beragregasi membentuk sumbatan trombosit pada proses hemostasis [10,13,20,22].

\section{Simpulan dan Saran}

Ekstrak rumput laut merah (Rhodophyceae) dapat berpengaruh dalam 
penurunan jumlah trombosit pada mencit diabetes. Ekstrak rumput laut merah menyatakan penurunan jumlah trombosit yang lebih optimal dari metformin.

Perlu dilakukan penelitian lebih lanjut yang memperhatikan mengenai senyawa bioaktif ekstrak rumput laut yang paling berpengaruh dalam penurunan jumlah trombosit pada mencit yang diabetes, menggunakan metode yang berbeda dalam penghitungan jumlah trombosit baik metode otomatis dan manual secara langsung serta secara tidak langsung untuk mengetahui keefektifan penghitungan jumlah trombosit dan memperhatikan penggunaan jenis pengencer ekstrak rumput laut seperti tween yang dapat berpengaruh terhadap hasil.

\section{Daftar Pustaka}

[1] Al Abri SA, Hayashi S, Thoren KL. Olson KR. Metformin Ovedose-induced in the absence of other diabetic drugs. Clin Toxicol; 2013. 51(5): 444-447.

[2] Arika WM, Rachuonyo HO, Muchori AN, Lagat RC, Mawia AM, Wambani JR, et al. Hypoglicemic effect of Ocimum lamiifolium in aloxan induced diabetic mice. Med Aromat Plants; 2016. 5(2): 1- 5.

[3] Atihuta F. Uji Aktivitas Ekstrak Kombinasi Batang dan Daun Suruhan (Piperumia pellucida L.H.B Kunth) Sebagai Antidiabetes pada Tikus Putih. Jurnal Mitra Pendidikan (JMP online). 2018; 2(2): 205216.

[4] BPPT. 2011. Outlook Energi Indonesia. Jakarta: Indonesia; 2011.

[5] Elsha Ukieyanna. Aktivitas Antioksidan, Kadar Fenolik, dan Flavonoid Total Tumbuhan Suruhan (Peperomia pellucida I. kunth) Skripsi. Institute Pertanian Bogor; 2012.

[6] Enrica M, Tristina N, Tjandrawati A. Rerata Volume Trombosit di Diabetes Melitus. Indonesian Journal of Clinical Pathology and Medical Laboratory. 2014; 21(1): 2427.

[7] Guidoni CM, Borges AP, Freitas OD, Pereira LR. Prescription Pattern for Diabetes Mellitus and Theurapethic
Implications: A Population-Based Analisys. Pharmaceutical Assistance and Clinical Pharmacy Research Center (CPAFF). Universitas Sao Paulo Brazil. 2012; 56(2).

[8] Lantah PL, Montolalu LADY, Reo AR. Kandungan fitokimia dan aktivitas antioksidan ekstrak metanol rumput laut Kappaphycus alvarezii. Jurnal Media Teknologi Hasil Perikanan. 2017; 5(3): 167173.

[9] Nawaly H, Susanto AB, Uktolseja. Senyawa Bioaktif dari Rumput Laut sebagai Antioksidan. Proceeding Biology Education Conference. 2013; 10(1).

[10] Palimbunga DP, Pandelaki, Mongan, Manoppo. Perbandingan Jumlah Trombosit pada Pasien Diabetes Melitus Tipe 2 yang Menggunakan Aspirin dan Tidak Menggunakan Aspirin. Jurnal e- Biomedik (eBM). 2013; 1(1): 202-209.

[11] Pramesti R, Ridlo A, Setyati WA, Zainuddin M. Aktifitas antioksidan rumput laut acanthopora muscoides (Linnaeus) bory dari pantai Krakal Gunung Kidul Yogyakarta. Jurnal Disprotek. 2017; 8(1): 46-56.

[12] Prisyanto R, Santoso DR, Juswono UP, Cahyati Y. Pengaruh pemberian kombinasi vitamin $\mathrm{C}$ dan $\mathrm{E}$ tehadap jumlah hemoglobin, leukosit dan trombosit pasca iradiasi sinar gamma. Natural B. 2014; 2(3): 290-295.

[13] Puspita ND, Langi, Yuanita A, Rotty

L. Hubungan kadar trombosit dan kejadian kaki diabetik pada penderita diabetes melitus tipe 2. Jurnal e-Clinic (eCl). 2015; 3(1): 363-367.

[14] Riwu M, Subarnas A, Lestari K. Korelasi Faktor Usia, Cara Minum, dan Dosis Obat Metformin Terhadap Risiko Efek Samping pada Penderita Diabetes Melitus Tipe 2. Jurnal Farmasi Klinik Indonesia. 2015; 4(3): 151-161.

[15] Sari FD. Pola Penggunaan Obat Anti Hiperglikemik Oral pada Pasien Diabetes Melitus Tipe 2 Rawat Inap di Rumah Sakit X Pekanbaru Tahun 2014. FK. 2016; 3(1):114.

[16] Shahriyari L. Yazdanparast R. Antiplatelet and antithrombotic activities of Artemisia dracunculus $L$. leaves extract. Pharmacology Online Inst. Biochem. 2009; 1:217-228. 
[17] Shalehah A, Cahaya N, Fadlilaturrahmah. Pengaruh Pemberian Ekstrak Etanol Daun Kajajahi (Leucosyke capitellata Wedd.) Terhadap Efek Pembekuan Darah dan Penurunan Agregasi Platelet pada Darah Manusia Sehat Secara In Vitro. Pharmacy. 2015; 12(02): 140-152.

[18] Soenardjo N. Aplikasi budi daya rumput laut Eucheuma cottonii (weber van bosse) dengan metode jaring lepas dasar (net bag) model Cidaun. Buletin Oseanografi Marina. 2011; 1:36-44.

[19] Syarif RA, Muhajir, Ahmad AR, Malik. Identifikasi Golongan Senyawa Antioksidan Dengan Menggunakan Metode Peredaman Radikal DPPH Ekstrak Etanol Daun Cordia myxa L. Jurnal Fitofarmaka Indonesia. 2013; 2(1):83-89.
[20] Szkudelski T. The mechanism of alloxan and sreptozotocin action in cells of the rat pancreas. Physiol. Res. 2001; 50: 536-546.

[21] WHO. Diet, Nutrition and the Prevention of Chronic Diseases. Geneva: World Health Organization; 2003.

[22] Widiarto NS, Posangi, Mongan, Memah. Perbandingan Jumlah Trombosit pada Diabetes Melitus Tipe 2 dengan Komplikasi Vaskular dan Tanpa Komplikasi Vaskular di RSUP Prof. Dr. R. D. Kandou Manado. Jurnal e- Biomedik (eBM). 2013; 1(1): 524529.

[23] Yanuarti R, Nurjanah, Anwar, Effionora, Hidayat, Taufik. Profil Fenolik dan Aktivitas Antioksidan dari Ekstrak Rumput Laut Turbinaria conoides dan Eucheuma cottonii. JPHPI. 2017; 20(2):230-237. 